\title{
DESAIN PEMBELAJARAN MEMVARIASI FABEL DENGAN MENGINTEGRASIKAN PENDIDIKAN ESTETIKA
}

\author{
Dyan Wahyuning Praharwati \\ Universitas Negeri Malang, dywapra27@gmail.com
}

\begin{abstract}
Curriculum is used as a foundation that contains technical rules. Curriculum used in the practice of education is currently 2013 curriculum. Language and literature Indonesia teaching should be implemented based on the national 2013 curriculum. In the 2013 curriculum KD 4.13 there are varying the fable/legend of the local area by changing the characters, setting, end of story, and serving on a secondary class VII. KD 4.13 learning especially for the text of the fable can be done by integrating the education of aesthetics. Aesthetic education strives to capture the beauty in works of literature. The aesthetics in literary works include aesthetics of language, aesthetic, cultural, aesthetic and transcendental. Integrating the education of aesthetics can be done by way of capturing such aesthetic forms in the works of literature. Aesthetics of literary works that captured can be used to perform variations against the fable. The activities of fables varying is done with structure, language, content, or genre varying. Fables varying learning can also be used to prepare the students to face the MEA. MEA is the current discourse concerning the renewal of the economic activities of the ASEAN community. Attempts to prepare the students to face the MEA can be done by way of a creative economy aiming by way of entering the field of publishing/printing as well as performances. Results of the study theory paper is focused on the discussion (1) fables varying learning, (2) the form of aesthetic value, (3) learning design of fables varying by aesthetic education integrated, and (4) the efforts of the creative economy was aiming for.
\end{abstract}

Key words: fabel varying, aesthetic value, creative economy

\section{PENDAHULUAN}

Evaluasi dan Revisi Kurikulum 2013 saat ini menjadi viral di masyarakat, khususnya pihak-pihak yang bersinggungan dengan pendidikan. Kurikulum 2013 bahkan disebut-sebut akan diganti dengan kurikulum baru yaitu Kurikulum Nasional. Pemberitaan atas penggantian Kurikulum 2013 dengan Kurikulum Nasional tersebut tidak dapat dibenarkan karena Menteri Pendidikan dan Kebudayaan, Anies Baswedan, memberikan penjelasan terhadap hal tersebut bahwa Kurikulum Nasional bukan nama kurikulum pengganti Kurikulum 2013 (JPNN, 2015). Pernyataan Anies Baswedan 
tersebut dapat dipahami bahwa kurikulum nasional bukanlah nama kurikulum pengganti Kurikulum 2013 melainkan kurikulum yang diberlakukan secara nasional. Nama kurikulum yang telah direvisi tidak berganti melainkan tetap menggunakan nama Kurikulum 2013. Lebih lanjut Anies Baswedan mengemukakan bahwa Kurikulum 2013 yang lalu hanya melalui dua tahap yaitu pendadaran ide dan penerapan. Hendaknya Kurikulum 2013 dijalalankan melalui empat tahap yaitu (1) pendadaran ide kurikulum, (2) pendesainan kurikulum, (3) pendokumentasian kurikulum, dan (4) penerapan kurikulum (JPNN, 2015).

Saat ini perjalanan revisi Kurikulum 2013 sampai pada tahap penerapan yang berarti bahwa pemberlakuan Kurikulum 2013 terevisi akan segera ditetapkan. Dinas Pendidikan Kota Yogyakarta mengusulkan pemberlakuan kurikulum nasional yaitu Kurikulum 2013 dimulai pada tahun ajaran 2016/2017 (Antara News, 2016). Jika Kurikulum 2013 terevisi benar akan diterapkan pada tahun ajaran 2016/2017, maka pelaku pendidik, khususnya guru, tidak memiliki banyak waktu untuk mempersiapkannya. Persiapan yang dilakukan guru antara lain memahami perubahanperubahan yang terdapat dalam Kurikulum 2013 terevisi, memperlajari struktur Kurikulum 2013 terevisi, menyiapkan pembelajaran berbasis Kurikulum 2013 terevisi, dan hal lain yang berkaitan dengan pelaksanaan pembelajaran berbasis Kurikulum 2013 terevisi.

Perubahan struktur Kurikulum 2013 tampak pada mata pelajaran Bahasa Indonesia. Salah satu perubahan yang dapat diamati adalah penggunaan kata kerja operasional. Penggunakan kata kerja operasional yang pada awalnya menggunakan kata memahami, membedakan, mengklasifikasi, dan mengidentifikasi kekurangan untuk merumuskan KD dalam KI 3 (reseptif) pada jenjang SMP direvisi dengan penggunaan kata mengidentifikasi, menelaah, serta menggali dan menemukan. Pada KI 4 (produktif) pada jenjang SMP pada awalnya menggunakan kata kerja operasional menangkap makna, menyusun, menelaah dan merevisi, serta meringkas direvisi dengan penggunaan kata memetakan, menyajikan, menceritakan kembali, menyimpulkan, menentukan, mengungkapkan, memerankan, memvariasikan, menulis, meringkas, dan menginterpretasi.

Memvariasi merupakan salah satu kata kerja operasional yang muncul dalam Kurikulum 2013 terevisi (Oktober 2015) pada jenjang SMP kelas VII. Kata kerja 312 | E-ISSN: 2527-8754 http:// journal.unesa.ac.id/index.php/Paramasastra 
operasional tersebut muncul dalam rumusan KD 4.13 yaitu memvariasikan fabel/legenda daerah setempat dengan mengubah penokohan, latar, akhir cerita, cara penyajian (serius menjadi parodi). Memvariasikan dalam KBBI berarti tindakan atau hasil perubahan dari keadaan semula. Kata kerja operasional memvariasikan dalam KD tersebut dapat diinterpretasi sebagai mengubah variasi struktur, bahasa, isi, bahkan genre. Pengubahan variasi struktur dapat dilakukan dengan mengubah alur cerita misalnya konflik berada pada awal cerita. Pengubahan bahasa dapat dilakukan dengan mengubah variasi bahasa. Pengubahan isi dapat dilakukan dengan mengubah unsur intrinsik seperti tokoh, latar, penokohan, dan sebagainya. Pengubahan genre atau alih genre dapat dilakukan dengan cara mengubah fabel yang menjadi pertunjukan drama, komik, dan sebagainya.

Pembelajaran memvariasikan fabel tentu tidak terlepas dari tantangan pemvariasian atau pengubahan. Sebelum melakukan kegiatan memvariasi siswa harus menangkap nilai-nilai estetika yang terdapat dalam fabel hipogram terlebih dahulu. Jika nilai estetika ditangkap dengan baik, maka karya transformasi yang dihasilkan oleh siswa akan memiliki esensi atau nilai estetika yang relatif sama dengan hipogramnya. Setelah mengetahui essensi cerita dengan cara menangkap nilai-nilai estetika, siswa dapat melakukan kegiatan memvariasi, baik variasi struktur, bahasa, isi, maupun genre.

Pilihan memvariasikan fabel dengan melakukan pengubahan struktur, bahasa, maupun isi akan menghasilkan bentuk karya sastra tertulis. Tantangan dalam menulis karya sastra adalah menulis dengan tidak terlalu memikirkan struktur dan kaidah bahasa. Pembelajaran menulis karya sastra yang masih memusatkan perhatian pada struktur dan kaidah bahasa merupakan pembelajaran yang bersifat struktural. Pembelajaran menulis karya sastra hendaknya memusatkan pada fungsinya agar pembelajaran lebih bermakna. Hal terpenting pada pembelajaran memvariasi fabel adalah siswa dapat memahami nilai estetika dalam fabel hipogram dan dapat menghasilkan karya transformasi yang memiliki esensi yang relatif sama.

Memvariasikan fabel dengan cara melakukan pengubahan genre atau alih genre akan menghasilkan sejumlah bentuk karya transformasi antara lain pertunjukan drama, komik, cerita berbasis audio-visual, dan sebagainya. Kegiatan mengalih-genrekan fabel hipogram ke dalam bentuk transformasi bergenre lain dapat dilakukan dengan menerapkan pembelajaran berbasis proyek. Proyek dapat diberikan guru sebagai tugas 
akhir semester atau sebagai tugas pengayaan. Pertimbangan untuk menjadikan kegiatan alih genre sebagai proyek adalah lamanya proses yang dibutuhkan untuk menyelesaikan proyek ini. Kegiatan pengalihan genre tidak dapat selesai dalam waktu satu hingga dua pertemuan saja, sehingga proses penyelesaian proyek ini relatif panjang.

Pembelajaran memvariasi fabel dapat menjadi strategi dalam membidik ekonomi kreatif. Saat ini merupakan era industri kreatif, yaitu aktivitas ekonomi yang semula berupa komoditas barang beralih menjadi komoditas kreatif. Cara membidik ekonomi kreatif tersebut dapat dilakukan dengan cara mencetak atau mengirimkan fabel transformasi ke pihak penerbitan maupun dengan cara membuat pertunjukan drama berdasarkan fabel.

Fokus bahasan pada makalah ini adalah desain pembelajaran memvariasikan fabel dengan mengintegrasikan pendidikan estetika dengan subbahasan (1) pembelajaran memvariasi fabel, (2) bentuk nilai estetika, (3) desain pembelajaran memvariasi fabel dengan mengintegrasikan pendidikan estetika, dan (4) upaya membidik ekonomi kreatif. Penelitian serupa pernah dilakukan oleh Wuriyani (2015) yang mengangkat judul Alih Wahana Legenda Asal Mula Danau Toba sebagai Strategi Ekonomi Kreatif dengan hasil berikut (1) karya sastra dapat berpotensi untuk menggerakkan ekonomi kreatif; (2) legenda Asal Mula Danau Toba menjadi buku dan pementasan merupakan bukti ide kreatif yang melihat potensi daerah; dan (3) penggalian potensi daerah tidak hanya bernialai ekonomi, namun sekaligus menjadi strategi untuk menggali, melestarikan, serta meopulerkan budaya lokal. Priyatni (2015) juga pernah melakukan penelitian berjudul Kesadaran Mengangkat Kearifan Lokal dalam Industri Kreatif: Studi Perbandingan terhadap Drama Seri serhadap Drama Seri Televisi Indonesia, India, dan Turki dengan hasil berikut (1) kearifan lokal mampu menjadi produk unggulan dan memiliki nilai jual dalam skala global serta (2) perlu adanya kesadaran untuk mengangkat kearifan lokal Indonesia dalam berbagai industri kreatif. Bercermin dari kedua penelitian yang telah dilakukan tersebut, makalah ini berupaya untuk mengangkat fabel nusantara yang merupakan warisan kebudayaan sebagai sumber ide kreatif untuk diangkat ke dalam industri kreatif melalui pembelajaran memvariasi fabel dengan mengintegrasikan pendidikan estetika. 


\section{PEMBAHASAN}

Bahasan pada makalah ini meliputi (1) pembelajaran memvariasi fabel, (2) bentuk nilai estetika, (3) desain pembelajaran memvariasi fabel dengan mengintegrasikan pendidikan estetika, dan (4) upaya membidik ekonomi kreatif.

\section{Pembelajaran Memvariasi Fabel}

Fabel banyak diartikan sebagai cerita yang tokoh-tokohnya adalah binatang. Bahkan terdapat pengertian bahwa fabel merupakan cerita tentang binatang. Pengertian seperti itu harus dikoreksi karena tokoh dalam fabel tidak harus binatang dan tidak menceritakan kehidupan binatang. Tomlinson dan Lynch-Brown (2002:105) mengungkapkan bahwa fabel merupakan cerita pendek yang memuat pelajaran moral dan biasanya menggunakan hewan sebagai tokoh. Penggunaan hewan dalam tokoh fabel sebagai simbol perilaku manusia dinilai efektif dan aman dari politik. Pendapat Tomlinson dan Lynch-Brown tersebut cukup menjelaskan bahwa binatang bukan tokoh mutlak dalam fabel hanya kecenderungan penulis fabel menggunakan tokoh hewan yang dinilai netral dan aman dari politik. Cerita yang disajikan juga bukan tentang hewan atau menceritakan tentang hewan namun cerita yang menginterpretasikan kehidupan manusia dengan tujuan untuk mengambil pelajaran moral.

Pendapat lain yang melengkapi pendapat Tomlinson dan Lynch-Brown adalah pendapat Lukens (2003:24) bahwa pelajaran moral yang menjadi tujuan dalam fabel dituangkan secara eksplisit namun jelas. Pendapat Lukens tersebut menegaskan cara penyampaian pelajaran moral dalam fabel tidak diungkapkan secara implisit atau terdapat dalam teks yang disajikan melainkan secara eksplisit. Cara menemukan pelajaran moral yang eksplisit ini dengan cara memahami cerita dan menginferensi pelajaran berharga yang termuat di dalamnya. Penyampaian pelajaran moral secara eksplisit namun jelas dapat dipahami bahwa dalam sebuah fabel memuat pelajaran moral yang tersirat namun jelas memiliki nilai positif.

Dengan demikian, fabel dapat diartikan sebagai cerita singkat yang menginterpretasikan kehidupan manusia dan memuat pelajaran moral dengan penggunaan tokoh cerita yang netral dan bebas politik misalnya hewan. Selain hewan tokoh yang dapat diangkat dalam sebuah fabel misalnya peralatan rumah tangga, kendaraan, benda alam, tanaman, dan sebagainya. 
Memvariasi menurut KBBI adalah tindakan atau hasil perubahan dari keadaan semula. Memvariasi dapat dipahami sebagai tindakan mengubah dari bentuk semula ke bentuk yang telah dimodifikasi atau bentuk lain. Dalam konteks pembelajaran memvariasi fabel, kegiatan memvariasi dapat dilakukan dengan cara memvariasikan struktur, bahasa, isi, maupun genre. Memvariasikan struktur, bahasa, dan isi akan menghasilkan bentuk karya sastra tertulis.

Memvariasikan struktur dapat dilakukan dengan mengubah urutan struktur konvensional cerita yang diawali dengan orientasi, komplikasi, dan diakhiri dengan resolusi misalnya menjadi komplikasi, resolusi, dan orientasi. Memvariasikan struktur juga dapat dilakukan dengan mengikuti struktur teks sastra lain misalnya naskah drama, puisi, dan sebagainya. Memvariasikan bahasa dapat dilakukan dengan mengubah diksi, mengubah atau menambah pendeskripsian peristiwa, mengubah atau menambah pendeskripsian latar cerita, mengubah atau menambah pendeskripsian tokoh serta penokohannya, dan sebagainya. Memvariasikan isi dapat dilakukan dengan mengubah maupun menambah unsur intrinsik misalnya mengubah atau menambah tokoh beserta penokohannya, mengubah latar cerita, menambah peristiwa, mengubah akhir cerita dan sebagainya.

Memvariasikan genre dapat dilakuan dengan mengalihwahanakan fabel ke dalam bentuk lain. Alih wahana adalah perubahan dari satu jenis kesenian ke jenis kesenian lain (Damono, 2005:96). Alih wahana merupakan pengubahan suatu jenis sastra atau kesenian ke jenis sastra atau kesenian lain. Misalnya pengubahan, cerita pendek menjadi drama, puisi menjadi lagu, novel menjadi film, dan sebagainya. Dalam konteks pembelajaran memvariasi fabel alih wahana dapat dilakukan dengan mengubah fabel menjadi pertunjukan drama, komik, cerita berbasis audio-visual, maupun pertunjukan musikalisasi puisi.

Hasil pemvariasian yang baik apabila memiliki esensi cerita yang sama. Esensi cerita dapat dilacak dengan mengetahui pesan atau pelajaran moral yang disampaikan. Jika pelajaran moral yang terdapat dalam karya sastra asli dapat tersampaikan pula dalam karya hasil variasi, maka kegiatan memvariasi tersebut berlangsung dengan baik. Dengan demikian, dalam konteks pembelajaran memvariasi fabel hendaknya sebelum melakukan kegiatan memvariasi dilakukan terlebih dahulu kegiatan menangkap dan memahami esensi cerita dalam fabel. 
Hubungan antarteks asli dengan teks hasil variasi dapat dikaji lebih lanjut dengan menggunakan pijakan teori intertekstual yang memandang suatu teks tentu memiliki teks lain yang memengaruhi dalam penciptaannya. Teks yang menjadi latar penciptaan karya baru disebut hipogram, dan teks baru yang menyerap dan mentransformasikan hipogram disebut teks transformasi (Riffaterre, 1978:11). Makalah ini tidak membahas lebih lanjut tentang kajian intertekstualitas, namun bahasan singkat tentang konsep intertektualitas ditujukan untuk meminjam istilah hipogram sebagai karya yang dijadikan acuan dan transformasi sebagai karya yang mengacu pada hipogram.

Berdasarkan hakikat fabel dan hakikat memvariasi yang telah disampaikan dapat disimpulkan bahwa memvariasi fabel dapat dilakukan dengan cara memvariasikan struktur, bahasa, isi, maupun genre fabel hipogram. Memvariasikan struktur, bahasa, dan isi menghasilkan karya sastra tertulis. Memvariasikan genre dapat menghasilkan bentuk karya lain. Memvariasikan struktur dapat dilakukan dengan mengubah urutan struktur atau mengikuti struktur teks sastra lain. Memvariasikan bahasa dapat dilakukan dengan mengubah diksi, mengubah atau menambah pendeskripsian peristiwa, mengubah atau menambah pendeskripsian latar cerita, mengubah atau menambah pendeskripsian tokoh serta penokohannya, dan sebagainya. Memvariasikan isi dapat dilakukan dengan mengubah maupun menambah unsur intrinsik. Memvariasikan genre dapat dilakuan dengan mengalihwahanakan fabel ke dalam bentuk lain.

Fabel hipogram digunakan sebagai acuan dalam menciptakan fabel transformasi. Dalam menciptakan fabel transformasi terlebih dahulu memahami esensi cerita dari fabel hipogram. Dengan demikian proses memvariasi berlangsung dengan baik karena pesan atau pelajaran moral yang terdapat dalam fabel hipogram dapat terinterpretasikan dalam fabel transformasi.

Bentuk Nilai Estetika

Sebuah karya sastra tentu memiliki nilai-nilai logika, etika, dan estetika. Logika dalam karya sastra muncul karena terdapat hubungan antara karya sastra dengan kenyataan-kenyataan yang ada. Logika merupakan hasil penalaran. Etika dalam karya sastra muncul karena karya sastra dapat dijadikan sumber panutan dalam bersikap. Estetika dalam karya sastra muncul karena karya sastra memiliki keindahan. Keindahan atau estetika dalam karya sastra tentu berbeda dengan karya yang lainnya. Estetika karya 
sastra Aspek-aspek keindahan dapat ditinjau melalui dua segi yang berbeda yaitu bahasa dan keindahan itu sendiri (Ratna, 2011:142). Lebih lanjut Mustopo menambahkan bahwa nilai estetika dalam sebuah karya sastra terdiri atas tiga hal besar yaitu estetika bahasa, estetika budaya, dan estetika transendental (1988:123).

Estetika bahasa merupakan keindahan susunan bahasa dalam karya sastra. Nilai estetika dapat ditinjau dari bahasa dan keindahan yang dibangun oleh karya sastra itu sendiri. Bahasa dalam karya sastra merupakan pembingkai keindahan yang berupa rangkaian beberapa unsur seperti alur cerita, tokoh, penokohan atau karakter, latar, sampai pesan yang ingin digambarkan dalam sebuah karya sastra.

Estetika budaya merupakan keindahan yang berasal dari budaya atau kebiasaankebiasaan manusia atau tokoh-tokoh dalam karya sastra. Estetika budaya ini menjadi penanda keunikan masing-masing budaya, misalnya budaya Jawa berbeda dengan budaya Sunda, dan sebagainya. sebuah karya sastra tentu memotret sebuah kejadian yang memiliki latar, termasuk salah satunya latar budaya ini.

Estetika transendental merupakan keindahan dari suatu keadaan yang tidak didasarkan pengalaman ataupun penalaran. Nilai transendental merupakan suatu yang bergerak di luar rentangan pengalaman manusia yang aktual atau sehari-hari dan juga tidak berdasar pada penalaran dan kekuatan mendeskripsikan. Nilai transendental tidak dapat ditemukan atau dipahamkan dengan pengalaman praktis melainkan diketahui dengan intuisi. Intuisi yang dimaksud adalah daya atau kemampuan mengetahui atau memahami sesuatu tanpa dipikirkan atau dipelajari, bisikan hati, gerak hati (Mustopo, 1988:123-129).

Desain Pembelajaran Memvariasi Fabel Dengan Mengintegrasikan Pendidikan Estetika

Menangkap nilai estetika dapat dilakukan untuk menangkap esensi cerita dalam fabel. Sikap yang diperlukan adalah menyerahkan diri sepenuhnya, masuk ke dalam dunia yang secara otonom disediakan oleh gejala kebudayaan tersebut (Ratna, 2011:33). Pernyataan Ratna dapat dipahami sebagai sikap yang menghayati karya sastra agar dapat menangkap dan memahami esensi cerita dalam karya sastra tersebut. Dalam konteks pembelajaran memvariasi fabel pendidikan estetika dapat dijadikan integrator. Pengintegrasian pendidikan estetika ke dalam pembelajaran memvariasikan fabel 
mengarahkan siswa pada kegiatan menangkap nilai-nilai estetika yang terdapat dalam karya sastra.

Menangkap nilai estetika berarti berupaya menangkap keindahan-keindahan yang terdapat dalam suatu karya sastra, dalam hal ini fabel. Seperti karya sastra lainnya, fabel menggunakan media bahasa dalam menyampaikan cerita. Nilai estetika dapat ditangkap melalui bahasa dalam karya sastra karena bahasa merupakan pembingkai keindahan sebuah karya sastra. Aspek-aspek keindahan dapat ditinjau melalui dua segi yang berbeda yaitu bahasa dan keindahan itu sendiri (Ratna, 2011:142). Pernyataan Ratna dapat dipahami bahwa nilai estetika dapat ditinjau dari bahasa dan keindahan yang dibangun oleh karya sastra itu sendiri. Bahasa dalam karya sastra merupakan pembingkai keindahan yang berupa rangkaian beberapa unsur seperti alur cerita, tokoh, penokohan atau karakter, latar, sampai pesan yang ingin digambarkan dalam sebuah karya sastra. Lebih lanjut Mustopo menambahkan bahwa nilai estetika dalam sebuah karya sastra terdiri atas tiga hal besar yaitu estetika bahasa, estetika budaya, dan estetika transendental (1988:123). Dengan demikian menangkap nilai estetika dalam karya sastra meliputi menangkap estetika bahasa, estetika budaya, dan estetika transendental.

Realisasi pengintegrasian pendidikan estetika dalam pembelajaran memvariasi dapat dilakukan dengan cara (1) siswa membaca dan memahami fabel hipogram, (2) siswa mengidentifikasi bahasa, struktur, dan isi yang meliputi unsur intrinsik fabel hipogram, (3) siswa membuat ringkasan berdasarkan hasil baca fabel hipogram, dan (4) memvariasi struktur/bahasa/isi/genre dengan memperhatikan esensi cerita. Langkah pertama merupakan langkah awal sebelum memvariasi fabel. Pada langkah ini siswa diinstruksi untuk membaca fabel hipogram pilihan, baik pilihan guru maupun pilihan sendiri serta memahami cerita yang dalam fabel tersebut.

Langkah kedua merupakan langkah menangkap nilai-nilai estetika dalam fabel. Pada langkah ini siswa diinstruksi untuk mengidentifikasi bahasa, struktur, dan isi yang meliputi unsur intrinsik fabel karena letak keindahan karya sastra terletak pada bahasa dan keindahan itu sendiri. Langkah ketiga juga merupakan realisasi menangkap nilai estetika. Pada langkah ini siswa diinstruksi untuk membuat ringkasan atau sinopsis berdasarkan fabel hipogram. Langkah ini setingkat lebih sulit dari pada langkah ketiga karena dapat menginterpretasikan pemahaman serta keberhasilan menangkap esensi cerita 
dalam fabel hipogram. Guru dapat mengecek tingkat pemahaman siswa terhadap fabel yang telah dibaca siswa dengan melihat hasil ringkasan atau sinopsis yang ditulis siswa.

Langkah keempat merupakan langkah terakhir sekaligus kegiatan akhir dari pembelajaran memvariasi fabel. Pada langkah ini siswa diinstruksi untuk memvariasi fabel hipogram baik pada aspek struktur, bahasa, isi, maupun genre. Memvariasikan fabel pada aspek struktur, bahasa, maupun isi dapat dilakukan dalam satu hingga dua pertemuan. Memvariasikan fabel pada aspek genre atau alih wahana tidak dapat dilakukan dalam satu atau dua pertemuan karena akan membutuhkan waktu dan proses yang relatif panjang sehingga hendaknya dibuat sebagai proyek akhir semester atau sebagai tugas pengayaan.

Implementasi pembelajaran memvariasi fabel dengan menginterpretasikan pendidikan estetika diuraikan dalam dua subbab berikut yang memaparkan langkah pembelajaran memvariasi fabel berintegrasi pendidikan estetika dengan pendekatan komunikatif dan pembelajaran memvariasi fabel berintegrasi pendidikan estetika dengan pendekatan berbasis proyek.

Langkah pembelajaran memvariasi fabel berintegrasi pendidikan estetika dengan pendekatan komunikatif digunakan untuk memvariasi fabel pada aspek struktur, bahasa, dan isinya karena tujuan pembelajaran dapat selesai dalam satu atau dua pertemuan. Pembelajaran berbasis komunikatif mementingkan penguasaan komunikasi nyata (Larsen dan Freeman, 2010:123). Dalam konteks pembelajaran memvariasi fabel dengan pendekatan komunikatif dilakukan agar dalam melakukan kegiatan memvariasi tidak memfokuskan perhatian pada struktur dan kaidah bahasa melainkan pada fungsinya agar pembelajaran lebih bermakna. Hal terpenting pada pembelajaran memvariasi fabel adalah kemampuan siswa mengubah struktur, bahasa, maupun isinya. Tahapan pembelajaran dengan pendekatan komunikatif yaitu (1) pembangunan konteks, (2) pemodelan teks, (3) pemecahan masalah bersama, dan (4) pemecahan masalah secara mandiri (Priyatni, 2014:119).

Langkah-langkah pembelajaran memvariasi fabel berintegrasi pendidikan estetika dengan pendekatan komunikatif yaitu (1) pembangunan konteks: guru menyampaikan manfaat memvariasi teks; (2) pemodelan teks: siswa membaca dan memahami fabel hipogram; (3) pemecahan masalah bersama: siswa mengidentifikasi bahasa, struktur, dan 
isi yang meliputi unsur intrinsik fabel hipogram; dan (4) pemecahan masalah secara mandiri: siswa membuat ringkasan berdasarkan hasil baca fabel hipogram dan memvariasi struktur/bahasa/isi/genre dengan memperhatikan esensi cerita.

Langkah pembelajaran memvariasi fabel berintegrasi pendidikan estetika dengan pendekatan berbasis proyek digunakan untuk memvariasi fabel pada aspek genreya atau alih wahana karena tujuan pembelajaran tidak dapat selesai dalam satu atau dua pertemuan melainkan membutuhkan waktu dan proses yang lama. Pembelajaran berbasis proyek merupakan pembelajaran yang mengorientasikan kegiatan belajar pada proyek. Langkah-langkah pembelajaran berbasis proyek yaitu (1) penentuan proyek, (2) perancangan langkah-langkah penyelesaian proyek, (3) penyusunan jadwal pelaksanaan proyek, (4) penyelesaian proyek dengan fasilitasi dan monitoring guru, (5) penyusunan laporan dan presentasi/publikasi hasil proyek, serta (6) evaluasi proses dan hasil proyek (Priyatni, 2014:123).

Langkah-langkah pembelajaran memvariasi fabel berintegrasi pendidikan estetika dengan pendekatan berbasis proyek yaitu (1) penentuan proyek: guru menyampaikan proyek alih wahana fabel, (2) perancangan langkah-langkah penyelesaian: siswa membagi kelompok dan membagi tugas, (3) penyusunan jadwal pelaksanaan: guru menentukan waktu pelaksanaan dan penyelesaian, (4) penyelesaian proyek: guru memeriksa secara berkala penyelesaian proyek siswa, (5) penyusunan laporan dan publikasi: siswa menyiapkan laporan/publikasi proyek, serta (6) evaluasi proses dan hasil: guru bersama siswa melakukan evaluasi.

\section{Upaya Membidik Ekonomi Kreatif}

Memvariasikan fabel dapat digunakan sebagai strategi dalam membidik industri kreatif. Inovasi guru dalam mengikutsertakan siswa meramaikan ekonomi kreatif dapat menumbuhsuburkan kepercayaan diri dan mengembangkan ide-ide kreatif yang dimiliki siswa. Lebih lanjut akan dipaparkan sebagai berikut.

Mengembangkan ide kreatif dapat dilakukan melalui kegiatan memvariasikan bentuk semula menjadi bentuk baru. Dalam konteks pembelajaran memvariasi fabel dapat dilakukan dengan memvariasi struktur, bahasa, isi, tas maupun genre. Pemvariasian ini akan menghasilkan bentuk karya baru yang berbeda dengan karya aslinya. Kreativitas 
siswa diarahkan untuk mengubah fabel hipogram menjadi karya transformasi. Dalam proses kreatif ini siswa tidak memiliki ruang untuk meniru apa yang dilakukan temannya karena kreativitas masing-masing anak berbeda dan akan menghasilkan karya transformasi yang berbeda pula.

Pembelajaran memvariasi fabel dapat melatih dan mengembangkan ide kreatif siswa. Kegiatan melatih dan mengembangkan ide kreatif ini merupakan bentuk penanaman karakter kreatif. Mengembangkan ide kreatif dalam pembelajaran memvariasi fabel sejalan dengan cita-cita Kurikulum 2013 yang mengusung pendidikan karakter. Salah satu karakter yang harus dikuasai siswa adalah karakter kreatif atau kreativitas. Dengan karakter kreatif siswa dapat mengolah serta mengembangkan sesuatu secara kreatif.

Selain mewujudkan pendidikan karakter, mengembangkan ide kreatif merupakan bekal untuk dapat membidik industri kreatif. Saat ini kegiatan ekonomi masyarakat telah bergeser dari komoditas berupa barang menjadi komoditas berupa karya-karya kreatif. Dalam bidang bahasa dan sastra karya kreatif dapat diwujudkan dengan menghasilkan tulisan kebahasaan maupun kesastraan. Salah satu cara untuk mewujudkan karya kreatif dalam bidang tersebut melalui pembelajaran memvariasi fabel. Pembelajaran memvariasi fabel menghasilkan fabel transformasi berdasarkan hipogramnya dengan memvariasikan struktur, bahasa, isi, maupun genre.

Di samping membidik ekonomi kreatif, mengenalkan dan mengangkat kearifan lokal juga dapat dilakukan dalam pembelajaran memvariasi fabel. Untuk dapat mengenalkan dan mengangkat kearifan lokal harus memperhatikan pemilihan fabel hipogram. Fabel yang dipilih sebagai hipogram hendaknya fabel nusantara yang mencerminkan kebudayaan Indonesia. Fabel asli nusantara seperti Harimau dan Gagak, Burung Taun dan Burung Ngulngul, maupun Pertarungan Rusa dan Kelomang (Utami dan Diyarto, 2013). Pemilihan fabel nusantara sebagai bahan karya kreatif yang ditujukan untuk membidik ekonomi kreatif akan menjadi produk unggulan serta memiliki nilai jual dalam skala global. 


\section{SIMPULAN}

KD memvariasi fabel dapat dilakukan dengan memvariasikan aspek struktur, bahasa, isi, maupun genre. Realisasi pengintegrasian pendidikan estetika dalam pembelajaran memvariasi dapat dilakukan dengan cara (1) siswa membaca dan memahami fabel hipogram, (2) siswa mengidentifikasi bahasa, struktur, dan isi yang meliputi unsur intrinsik fabel hipogram, (3) siswa membuat ringkasan berdasarkan hasil baca fabel hipogram, dan (4) memvariasi struktur/bahasa/isi/genre dengan memperhatikan esensi cerita. Pembelajaran memvariasi fabel dapat melatih dan mengembangkan ide kreatif siswa, membidik ekonomi kreatif, serta dapat mengenalkan dan mengangkat kearifan lokal.

\section{DAFTAR RUJUKAN}

Antara News. 2016. Yogyakarta Usulkan Pemberlakuan Kurikulum Nasional. (Online), (http://www.antaranews.com/berita/537890/yogyakarta-usulkan-pemberlakuankurikulum-nasional), diakses 10 April 2016.

Damono, Sapardi D. 2005. Pegangan Penelitian Sastra Bandingan. Jakarta: Pusat Bahasa Departemen Pendidikan Nasional.

JPNN. 2015. Mendikbud: K-13 Tetap Berlaku. (Online), (http://www.jpnn.com/read/2015/12/30/347693/Mendikbud:-K-13-TetapBerlaku-), diakses 10 April 2016.

Larsen, D. dan Freeman. 2010. Techniques and Principles in Language Teaching. New York: Oxford University Press.

Lukens, Rebecca J. 2003. A Critical Handbook of Children's Literature. New York: Allyn and Bacon.

Mustopo, H. 1988. Ilmu Buda ya Dasar: Kumpulan Essay Manusia dan Budaya. Surabaya: Usaha Nasional.

Priyatni, Endah T. 2014. Desain Pembelajaran Bahasa Indonesia dalam Kurikulum 2013. Jakarta: Bumi Aksara. 
Priyatni, Endah T. 2015. Kesadaran Mengangkat Kearifan Lokal dalam Industri Kreatif: Studi Perbandingan terhadap Drama Seri Televisi Indonesia, India, dan Turki. Makalah disajikan pada Prosiding Seminar Nasional Sabastra 2015: Bahasa, Sastra, dan Seni di Era Industri Kreatif, Fakultas Sastra Universitas Negeri Malang, Malang, 14 November 2015.

Ratna, Nyoman K. 2011. Estetika Sastra dan Budaya. Yogyakarta: Pustaka Pelajar.

Riffaterre, M. 1978. Semiotics of Poetry. Bloomington: Indiana University Press.

Tomlinson, Carl M. dan Lynch-Brown, C. 2002. Essentials of Children's Literature. New York: Allyn and Bacon.

Utami, N. dan Diyarto R. 2013. 63 Legenda, Cerita, Mitos, Fabel Nusantara. Jakarta: Trans Media.

Wuriyani, Elly P. 2015. Alih Wahana Legenda Asal Mula Danau Toba sebagai 